This is the final peer-reviewed accepted manuscript of:

S.Consoli, M.Milani, G.Cirelli, S.Barbagallo, A.Marzo, D.Vanella, A.Toscano "Energy and water balance of a treatment wetland under mediterranean climatic conditions" which has been published in final form in Ecological Engineering, Volume 116, June 2018, Pages 52-60

The final published version is available online at:

https://doi.org/10.1016/j.ecoleng.2018.02.029

(C) 2018 Elsevier. This manuscript version is made available under the Creative Commons Attribution-NonCommercial-NoDerivs (CC BY-NC-ND) 4.0 International License (http://creativecommons.org/licenses/by-nc-nd/4.0/) 


\title{
Energy and water balance of a treatment wetland under mediterranean climatic conditions
}

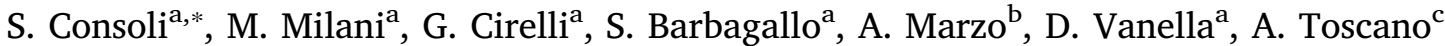 \\ ${ }^{a}$ Dipartimento di Agricoltura, Alimentazione e Ambiente, Università degli Studi di Catania, Via S. Sofia, 100, 95123 Catania, Italy \\ b CUTGANA, Centro Universitario per la Tutela e la Gestione e degli Ambienti Naturali e degli Agroecosistemi, Via Santa Sofia, 98 , 95123 Catania, Italy \\ ${ }^{\mathrm{c}}$ Dipartimento di Scienze e Tecnologie Agro-Alimentari, Alma Mater Studiorum Università degli Studi di Bologna, V.le Fanin 50, 40127 Bologna, Italy
}

\begin{abstract}
A B S T R A C T
During 2013-2014 period, the surface renewal (SR) - energy balance (EB) method combined with the water balance approach was adopted to define the energy and water budget of a treatment wetland (TW) in Eastern Sicily (Italy). The main objective was to evaluate the differences between energy and water balances and understand the underlining mechanisms of environmental control. Results shown that the seasonal variation in evapotranspiration (ET) had similar trend as the seasonal variation of leaf area index (LAI) and net radiation $\left(R_{n}\right)$. During the study period, the daily rate of ET by EB ranged from $-0.1 \mathrm{~mm} \mathrm{~d}^{-1}$ to $9.3 \mathrm{~mm} \mathrm{~d}^{-1}$, with a total ET of about $1837 \mathrm{~mm}$ in 17 months. The crop coefficient $\mathrm{K}_{\mathrm{c}}$ (e.g. obtained using the FAO-56 mean $\mathrm{K}_{\mathrm{c}}$ approach) for the TW ranged from 0.5 to 2.4, with a mean annual value of 1.24. On a 10-day mean basis, ET fluxes from the TW water balance were $15 \%$ higher than ET by EB.
\end{abstract}

Keywords:

Treatment wetland

Evapotranspiration

Surface renewal

Water balance

\section{Introduction}

Treatment wetlands $\left(\mathrm{TW}_{\mathrm{s}}\right)$ are designed plants where the natural mechanisms and interactions of vegetation, soils and the microbial populations contribute to reduce surface water or wastewater contaminants (Headley et al., 2012). Their use, as decentralized systems for the treatment of domestic water, is increasingly mainly due of their low operation and maintenance requirements (Cirelli et al., 2007, Barbagallo et al., 2003, 2011) and low risk associated to human contact.

In $\mathrm{TW}_{\mathrm{s}}$, water cycle and the associated energy exchange process have a fundamental role in the operation of these systems (Rejšková et al., 2012). The wetland plants, both in natural wetlands and in those constructed, are adapted to grow in a not limited water availability conditions, with associated high evapotranspiration (ET) rate (Borin et al., 2011).

A detailed knowledge of ET can be crucial for the functioning of $\mathrm{TW}_{\mathrm{s}}$. In fact, especially when the treated water are indispensable resources to be reused for irrigation (Barbagallo et al., 2012, Toscano et al., 2013, Castorina et al., 2016), excessive ET losses may increase salt concentrations in the effluent (Headley et al., 2012).

The hydrological processes occurring in $\mathrm{TW}_{\mathrm{s}}$, such as horizontal flow wetlands, are different from those in the natural wetland systems, due to the infiltration and surface runoff exclusion and the identification of stream flow with wastewater influent and effluent (Headley et al., 2012), which can be measured with flow metering devices. In these systems, the direct measurement of ET fluxes generally present difficulties (Price, 1994, South et al., 1998, Moro et al., 2004, Noormets et al., 2006).

Several studies have explored how to directly measure or estimate ET fluxes from natural or TW systems (e.g. Idso, 1981, Idso and Anderson, 1988, Abtew and Obeysekera, 1995, Soucha et al., 1996, Wilson and Baldocchi, 2000, Drexler et al., 2004 Toscano et al., 2015), and ET term has become a subject of debate. However, few studies have dealt with the analysis of the relationship between ET, the surface energy fluxes and the related physical processes especially in TW systems (Goulden et al., 2007, Clulow et al., 2012). Different procedures of direct measurement or estimation of ET fluxes were adopted, and, as consequence, significantly different results were obtained, thus contributing to increase the uncertainty about the most appropriate methods for treatment wetland ET determination.

Relevant studies were conducted by Abtew and Melesse (2013) on ET direct measurement by lysimeters, other by Burba et al. (1999) and Peacock and Hess (2004) on the adoption of micrometeorological methods, based on the energy fluxes budget, to measure ET from wetland systems.

Among the micrometeorological methods, the eddy covariance (EC) technique is recognized as one of the most accurate for estimating 
wetland ET (Acreman et al., 2003, Goulden et al., 2007, Siedlecki et al., 2016), even if it involves relevant instrumental costs (Clulow et al., 2012) and specialized personnel for data processing. An important advantage of the EC method is that the obtained water vapour flux comes from a source area within a distance of $200-300 \mathrm{~m}$ from the sensor.

In the recent past, the applied research has recognized the Surface Renewal (SR) technique as valid alternative to EC sonic anemometer for sensible heat flux $(\mathrm{H})$ direct measurements (Drexler et al., 2004). The SR is reasonable accurate, cheaper than EC and easily maintained for heterogeneous systems measurements like wetlands. When SR is integrated with direct measurements of net radiation and soil heat flux, it allows to estimate ET as residual of the energy balance equation.

Other studies conducted within treatment wetlands have calculated ET fluxes by the resolution of the water balance using off-site data (Kadlec and Wallace, 2008) or by simple meteorological equations such as the Penman-Monteith model, and other hydrological and cropgrowth models (Annandale et al., 2003, van Heerden et al., 2009). The use of these models requires vegetation specific parameters for calibration (Mao et al., 2002).

In this study, the eddy covariance (EC) method was adopted over a period from July 2013 to December 2014, to determine energy fluxes and ET from a treatment wetland system in Eastern Sicily (Italy). The results on ET fluxes were compared to ET estimates from both a hydrologic water balance of the wetland and the FAO-56 PenmanMonteith model. The valuable alternative technique surface renewal (SR) was also adopted at the site to estimate sensible heat fluxes $\left(\mathrm{H}_{\mathrm{SR}}\right)$ from TW areas. The results on ET fluxes were compared to ET estimates from both a hydrologic water balance of the wetland and the FAO-56 Penman-Monteith model.

The results of this study are crucial from the point of view of the works aimed at assessing the role of ET in the functioning of the TW systems. Moreover, despite the extensive research on the topic of TW, there are still few studies on the complex characteristics of evapotranspiration in Italy's full-scale wetland systems.

\section{Materials and methods}

\subsection{The study site}

The study site is the largest TW of Sicily (South Italy), used as tertiary wastewater treatment of 5000 Persons Equivalent (PE) (Fig. 1).

It is located in the small village of S. Michele di Ganzaria in Eastern Sicily $\left(37^{\circ} 17^{\prime} 0^{\prime \prime} \mathrm{N}, 14^{\circ} 26^{\prime} 0^{\prime \prime} \mathrm{E}\right)$. The TW areas $\left(12,700 \mathrm{~m}^{2}\right)$ is part of the wastewater reuse project of the village, consisting of four horizontal sub-surface (H-SSF) reed beds (H-SSF1, H-SSF2, H-SSF3 and H-SSF4), followed by three batch wastewater storage reservoirs (S1, S2 and S3) working in parallel (Fig. 2) (Castorina et al., 2016).

The sewerage system collects wastewater from almost every household in a conventional wastewater treatment plant (WWTP), north-west of San Michele di Ganzaria, where urban wastewater receive a pre-treatment step followed by two parallel water lines (Imhoff tank, trickling filter and a secondary sedimentation tank). For tertiary treatment, the effluent is sent in four H-SSF beds (about $2 \mathrm{~L} \mathrm{~s}^{-1}$ per bed), of which H-SSF1 and H-SSF2 are in operation respectively since 2001 and 2006, while H-SSF3 and H-SSF4 since summer 2013.

The research focused on the study of the H-SSF3 TW bed, that has a surface area of about $2300 \mathrm{~m}^{2}(36 \times 64 \mathrm{~m})$ and a theoretical flow rate of about $173 \mathrm{~m}^{3} \mathrm{~d}^{-1}$. The TW depth (e.g. $0.6 \mathrm{~m}$ ) is filled with $8-10 \mathrm{~mm}$ of volcanic gravel. The TW bottom has a slope of $1 \%$ and the average water depth is $0.5 \mathrm{~m}$. Both the excavated beds and banks were lined with a $4 \mathrm{~mm}$ thick bentonite sheet to prevent groundwater contamination. Earth banks, with a slope of 3:1, were covered with jute netting to facilitate vegetation and prevent soil erosion. In September 2012, the H-SSF3 was planted with Phragmites australis (Cav.) Trin. ex Steud at a density of one rhizome $\mathrm{m}^{-2}$; the complete plant cover was reached a year later. The vegetation had average maximum height of $2.0 \mathrm{~m}$, with homogeneous canopy cover and no areas of fully exposed substrate and plant roots were in water saturation conditions. The leaf area index (LAI) ranged between $0.4 \mathrm{~m}^{2} \mathrm{~m}^{-2}$ in winter and $5.0 \mathrm{~m}^{2} \mathrm{~m}^{-2}$ in summer.

In the TW, the influent is distributed at the bed-head through a perforated $200 \mathrm{~mm}$ PVC pipe above the substrate and oriented normal to the flow direction to allow homogenous wastewater distribution. Wastewater is intercepted downstream by a cross perforated pipe located in the final section at the bottom of the bed. Electromagnetic flow meters (ISOIL mod. MS2500), installed at the inlet and at the outlet pipes, measure the flow rate $\left(\mathrm{Ls}^{-1}\right)$ in continuous. In the bed, nine piezometers (i.e. $0.2 \mathrm{~m}$ of diameter) were arranged in 3 rows; they consist of open perforated plastic tubes inserted into the substrate to the bottom of the bed, used to measure the water height and to collect wastewater samples.

The wetland area has been instrumented with an automatic weather station (Campbell Scientific, Logan, UT) to measure air temperature, wind speed and direction, rainfall, global radiation and relative humidity. These data were used to calculate the Penman-Monteith equation (Allen et al., 1998) for reference ET $\left(\mathrm{ET}_{0}\right)$ estimation. The FAO-56 Penman-Monteith model provides estimates of hourly ET from a hypothetical grass reference surface $\left(\mathrm{ET}_{0}\right)$ (Eq. (1)). It is well-known to estimate the crop coefficient $\left(\mathrm{K}_{\mathrm{c}}\right)$ as ratio between crop evapotranspiration during no water-stress conditions $\left(\mathrm{ET}_{\mathrm{c}}\right.$, in turn ET from EC or ET from TW water balance) and $\mathrm{ET}_{0}$.
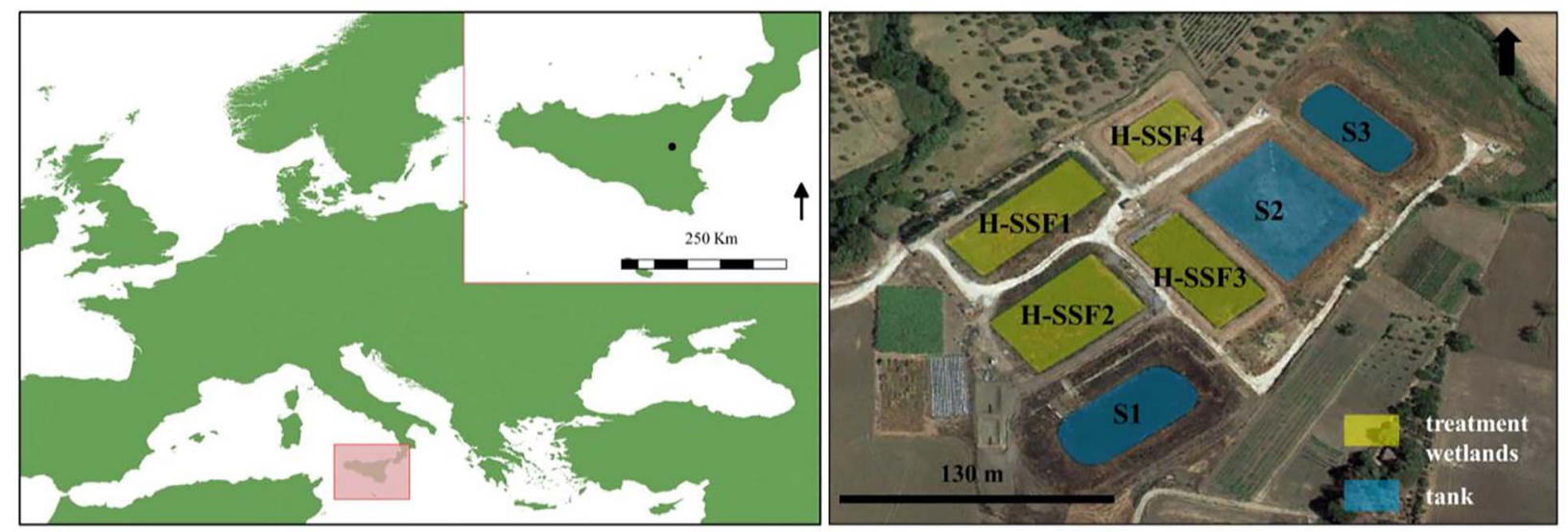

Fig. 1. Geographical location of the treatment wetland areas in Eastern Sicily. 


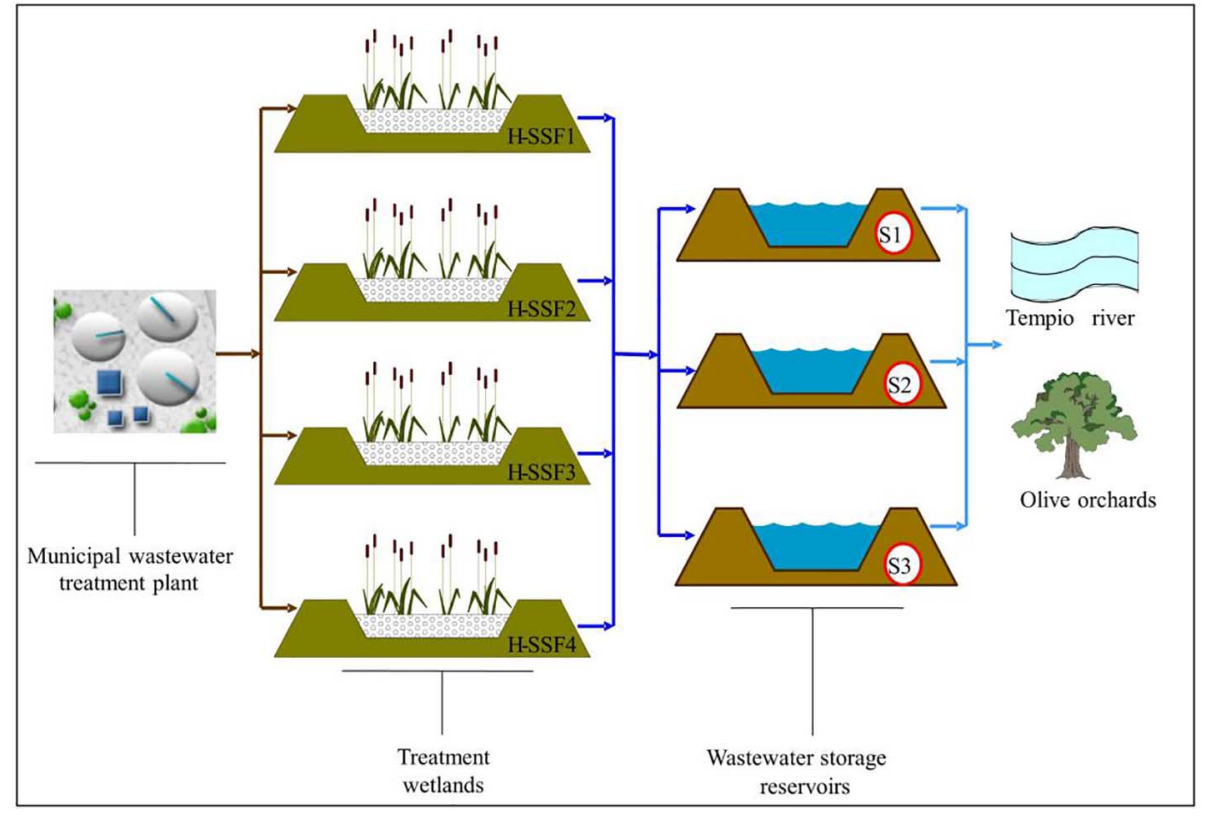

Fig. 2. Layout of the treatment wetland areas in Eastern Sicily.

$$
E T_{0}=\frac{0.408 \Delta\left(R_{n}-G\right)+\gamma \frac{900}{T+273} u_{2}\left(e_{s}-e_{a}\right)}{\Delta+\gamma\left(1+0.24 u_{2}\right)}
$$

In Eq. (1), $\Delta$ is the slope of the saturation vapour pressure at the air temperature ( $\mathrm{kPa} o \mathrm{C}-1), \gamma$ is the psychrometric constant $(\mathrm{kPa} o \mathrm{C}-1)$, $\mathrm{T}$ is the daily (or hourly) mean temperature $\left({ }^{\circ} \mathrm{C}\right.$ ), $\mathrm{u} 2$ is the mean wind speed in $\mathrm{m} \mathrm{s}^{-1}$, and es-ea is the vapour pressure deficit $(\mathrm{kPa})$.

\subsection{Micrometeorological measurements}

In July 2013, a micrometeorological energy balance tower was installed at the H-SSF3 TW bed. It was equipped with eddy covariance
(EC) sensors (Kaimal and Finnigan, 1994a,b), mounted at $4 \mathrm{~m}$ of height (about twice the plant maximum height) (Fig. 3).

At the site, net radiation $\left(\mathrm{R}_{\mathrm{n}}, \mathrm{W} \mathrm{m}^{-2}\right)$ was measured with a NR Lite net radiometer (Kipp\&Zonen, Campbell Scientific Ltd) at a height of $6 \mathrm{~m}$. Heat flux density $\left(\mathrm{G}, \mathrm{W} \mathrm{m}^{-2}\right.$ ) was estimated as mean value of three heat flux plates measurements (HFP01, Campbell Scientific Ltd). The plates were inserted $0.05 \mathrm{~m}$ below the saturated substrate surface.

The air temperature and the three wind speed components were measured using a fine wire thermocouples (CS FW3, $0.0762 \mathrm{~mm}$ diameter) located at the roughness sub-layer, about $0.5 \mathrm{~m}$ above the canopy top, and a sonic anemometer (CSAT, Campbell Sci., at $8 \mathrm{~m}$ ) at $4 \mathrm{~m}$

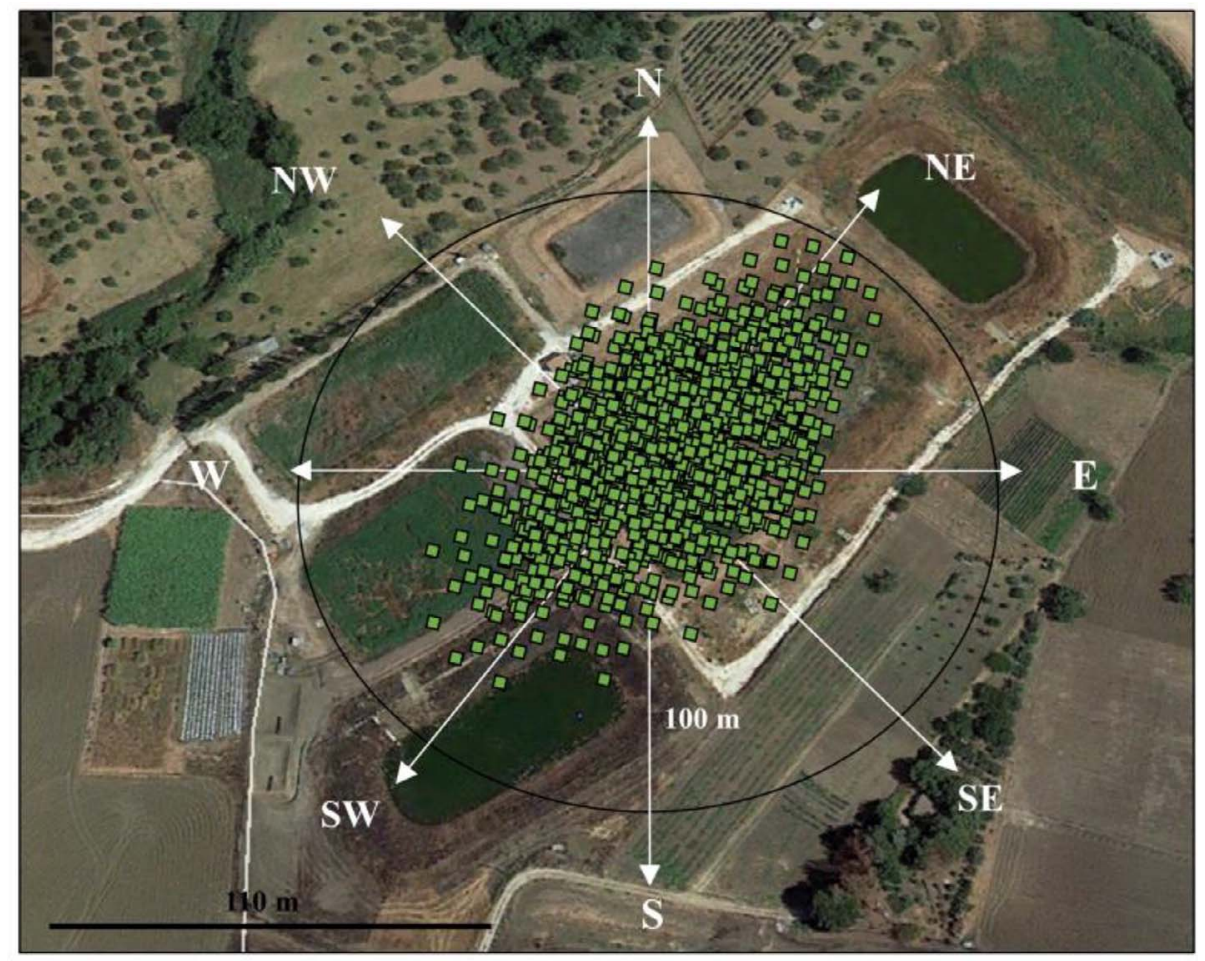

Fig. 3. Eddy covariance footprint area of the TW system of S. Michele di Ganzaria. 


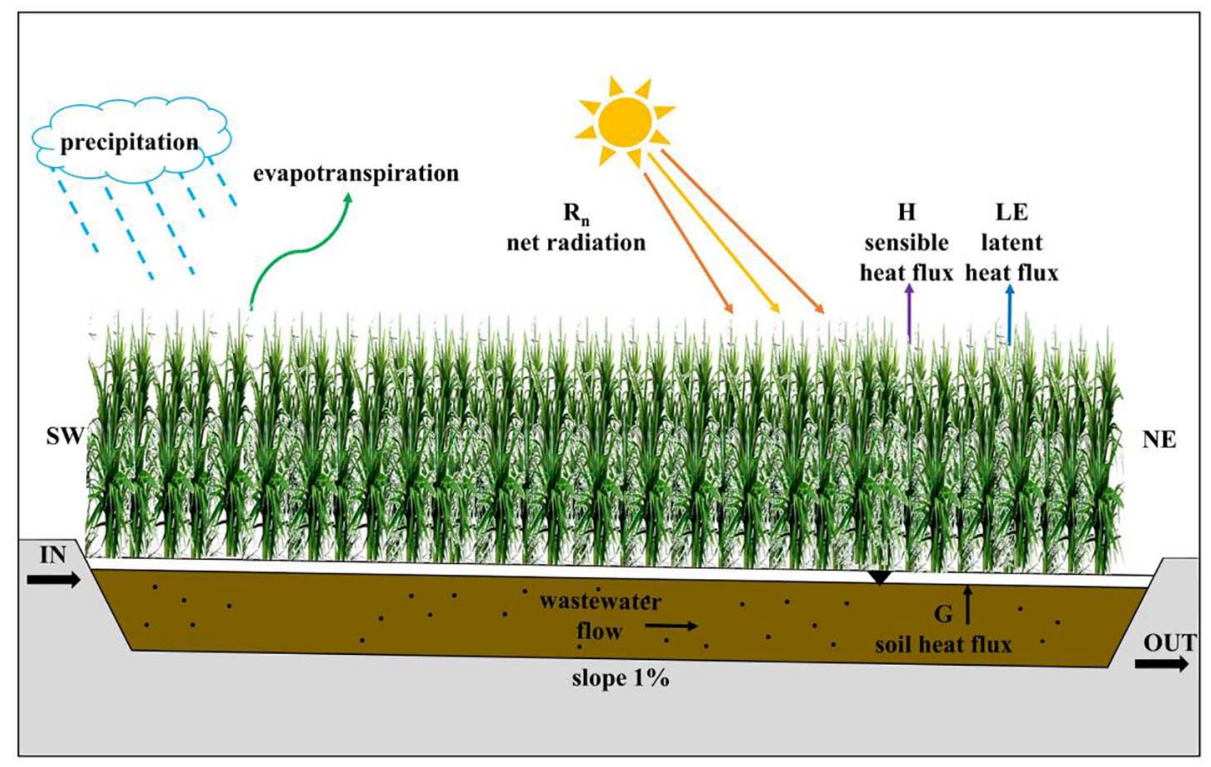

Fig. 4. Energy and water balance at the TW system.

of height, respectively. An infrared gas analyzer (LI-7500, LI-COR) located at $4 \mathrm{~m}$ was used for $\mathrm{H}_{2} \mathrm{O}$ and $\mathrm{CO}_{2}$ acquisitions. The EC data were recorded at $20 \mathrm{~Hz}$ of frequency. Fig. 3 shows the footprint area at the study site.

The standard EUROFLUX rules (Aubinet et al., 2000) were used for EC measurements and data processing. A data quality check was applied during the post processing together with some routines to remove the common errors: running means for detrending, three angle coordinate rotations and despiking. Stationarity and surface energy closure were also checked (Kaimal and Finnigan, 1994a,b).

To avoid underestimation of evapotranspiration, data gap on EC measurements were filled before determining the daily values. Gaps of several hours were filled using the average daily pattern of values calculated over a period of 14 days (Foken, 2008). On the other hand, in assessing the daily pattern of evapotranspiration, series with unfilled measurement gaps were used. This approach allowed to determine the statistic variability only on the basis of the EC data.

The eddy covariance sensible heat flux $\mathrm{H}\left(\mathrm{W} \mathrm{m}^{-2}\right)$ was calculated as:

$H_{E C}=\rho \cdot c_{p} \cdot \sigma_{w T}$

with, $\rho\left(\mathrm{g} \mathrm{m}^{-3}\right)$ : air density, $\mathrm{c}_{\mathrm{p}}\left(\mathrm{J} \mathrm{g}^{-1} \mathrm{~K}^{-1}\right)$ : air specific heat capacity at constant pressure and $\sigma_{\mathrm{wT}}\left(\mathrm{m} \mathrm{s}^{-1} \mathrm{~K}\right)$ : covariance between the vertical wind speed and air temperature.

The flux of water vapour content, i.e. the latent heat flux (LE, $\mathrm{W} \mathrm{m}^{-2}$ ), was expressed as:

$L E_{E C}=\lambda \cdot \sigma_{w q}$

with, $\lambda\left(\mathrm{J} \mathrm{g}^{-1}\right)$ : latent heat of vaporization and $\sigma_{w q}\left(\mathrm{~m} \mathrm{~s}^{-1} \mathrm{~K}\right)$ : covariance between the vertical wind speed and water vapour concentration.

30-min latent heat fluxes, acquired in $\mathrm{W} \mathrm{m}^{-2}$, aggregated to a daily scale were transformed to ET rate $\left(\mathrm{mm} \mathrm{d}^{-1}\right)$ (Mauder and Foken, 2004; Mauder et al., 2007).

In the study, the surface renewal (SR) technique (Paw and Brunet, 1991, Snyder et al., 1996) was adopted to estimate the sensible heat flux density (Eq. (4)); SR was considered as alternative technique to the EC sonic anemometer. The technique required high frequency temperature data $(4 \mathrm{~Hz})$, collected using one $76.2 \mu \mathrm{m}$ thermocouple mounted $0.5 \mathrm{~m}$ above the canopy top. The traces of temperature have ramp like characteristics, which were analysed to compute the mean ramp amplitude $(a)$ and the inverse ramp frequency $(d+s)$ using structure functions (Van Atta, 1977).
$H_{S R}=\alpha \rho C_{p}\left(\frac{a}{d+s}\right) z$

The factor $\alpha$ accounts for the unequal heating below the sensors (Paw et al., 1995, Snyder et al., 1996, Spano et al., 1997); $\rho$ : air density $\left(\mathrm{g} \mathrm{m}^{-3}\right)$ and $C_{p}$ : specific heat of air at constant pressure $\left(\mathrm{J} \mathrm{g}^{-1} \mathrm{~K}^{-1}\right)$. The ratio $\frac{a}{d+s}$ is the mean change in temperature $\left({ }^{\circ} \mathrm{C}\right.$ or $\left.\mathrm{K}\right)$ with time (seconds) during the sampling interval (i.e. $30 \mathrm{~min}$ in these experiments).

In the study, sensible heat flux data from SR technique $\left(\mathrm{H}_{\mathrm{SR}}\right)$ were calibrated with independent measurements of EC by the 3-D sonic anemometer. The calibration data allowed to obtained the $\alpha$ value of Eq. (3) by simple linear regression forced through the origin.

After calculating $H_{S R}, L E$ was the residual term of the energy balance equation (Eq. (5)) on a half-hourly basis:

$L E=R_{n}-G-H$

Daily $\mathrm{ET}_{\mathrm{EC}}$ were compared with $\mathrm{ET}_{\mathrm{SR}}$ and the FAO-56 PenmanMonteith model.

\subsection{The water balance equation}

At the TW, a daily water balance was computed as follows:

$P-E T+I N-O U T+\Delta S=0$

with P: precipitation (mm), ET: evapotranspiration (mm), IN and OUT: inflow (mm) and outflow $(\mathrm{mm})$, which represent the wastewater inflow and outflow controlled by pumps (Fig. 4) and $\Delta S$ : change in water storage $(\mathrm{mm})$ in the saturated substrate. The water storage $\Delta S$ was neglected, since piezometers levels were similar during the experimental period. The simplified Eq. (6) was then solved to determine daily ET rates.

\section{Results}

\subsection{Results on micrometeorological measurements and energy balance}

A seasonal variation in air temperature characterized the study period (Fig. 5), with the warmest monthly mean temperature of $23.6^{\circ} \mathrm{C}$ in July and the coldest value of $9.0^{\circ} \mathrm{C}$ in December. Monthly precipitation showed a large variability, with most rainfall during December-March as typical of semi-arid climatic conditions. In 2014, the annual precipitation was $470 \mathrm{~mm}$, and the corresponding annual mean 


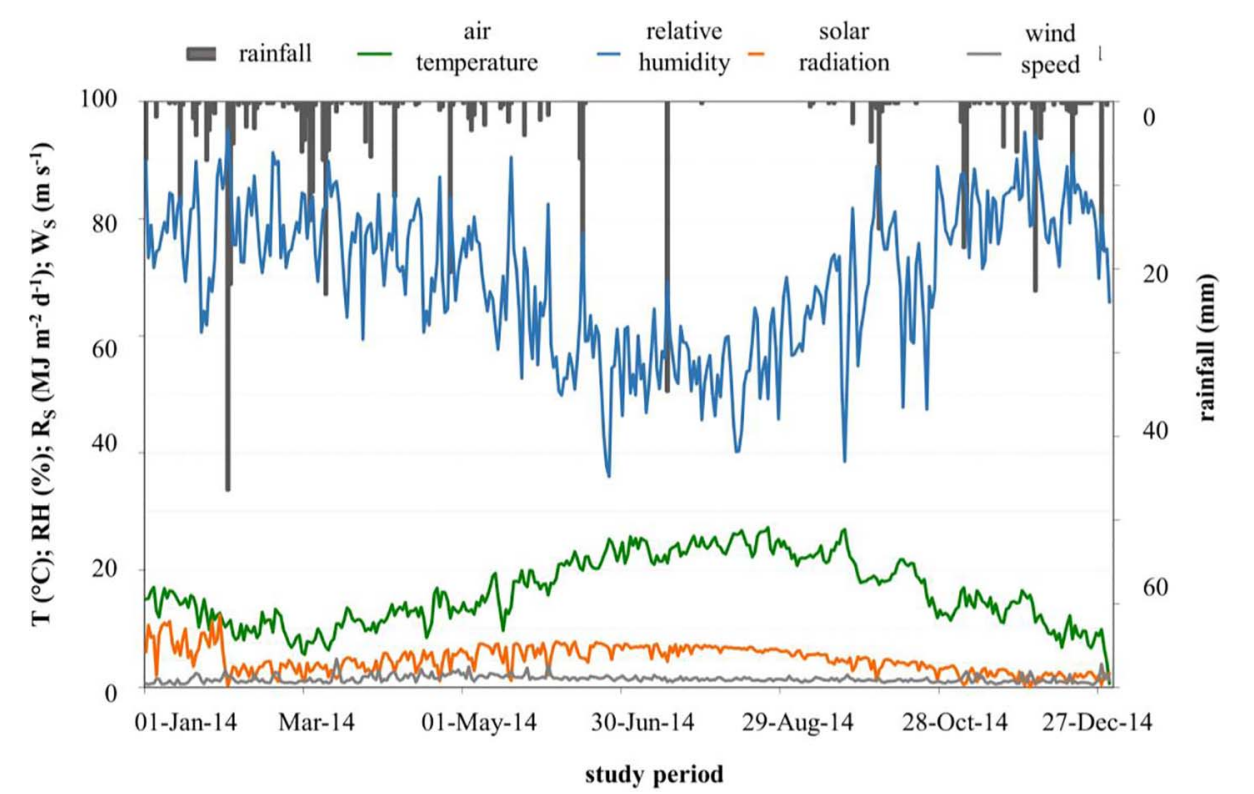

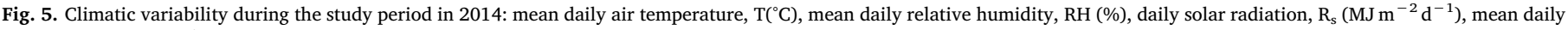
wind speed, $\mathrm{W}_{\mathrm{s}}\left(\mathrm{m} \mathrm{s}^{-1}\right)$.

value of air temperature was $16^{\circ} \mathrm{C}$.

The sum of latent (LE) and sensible (H) heat measured by the eddy covariance (EC) system located within the TW system was linearly correlated with the available energy, $\mathrm{R}_{\mathrm{n}}-\mathrm{G}$ at the 30 -min time scale (Fig. 6a and b).

The energy balance closure was 0.89 and 0.90 in 2013 and 2014, respectively. These high values suggested reliable energy balance measurements (Consoli and Papa 2013) to examine the energy partitions within the studied treatment wetland.

The mean hourly net radiation $\left(R_{n}\right)$ flux was of $120( \pm 212) \mathrm{Wm}^{-2}$. $R_{n}$ during the summer period (July-September) of the two years of trial had an hourly mean of $166( \pm 259) \mathrm{Wm}^{-2}$. The latent heat flux from eddy covariance $\left(L_{E C}\right)$ was correlated with $R_{n}$, with a determination coefficient of 0.78 ; $\mathrm{LE}_{\mathrm{EC}}$ had an hourly mean of $110( \pm 286) \mathrm{Wm}^{-2}$, with a mean hourly value during summer of $213( \pm 193) \mathrm{Wm}^{-2}$. The hourly mean sensible heat flux from eddy covariance $\left(\mathrm{H}_{\mathrm{EC}}\right)$ was of $20( \pm 123) \mathrm{Wm}^{-2}$, with a summer mean value of $30( \pm 76) \mathrm{Wm}^{-2}$. Hourly average soil heat flux (G) was of $-4.3( \pm 9.7) \mathrm{Wm}^{-2}$, with few positives during summer. The maximum value of $30-\mathrm{min} \mathrm{G}$ at a $5-\mathrm{cm}$ depth was of $33.5 \mathrm{Wm}^{-2}$. The minimum $30-\mathrm{min} \mathrm{G}$ was of $-57 \mathrm{Wm}^{-2}$ during early morning hours. Overall $\mathrm{G}$ was a minor component of the overall energy balance of the TW system.

Energy partitioning showed a clear seasonal variability (Fig. 7).

The $\mathrm{LE}_{\mathrm{EC}}$ dominated the energy balance, reaching the maximum of
$22.8 \mathrm{MJ} \mathrm{m}^{-2} \mathrm{~d}^{-1}$ at the end of July 2014. During the dormant period (October-February) and when rainfall increased the soil water content, LE was similar to $\mathrm{H}$.

The mean daily $\mathrm{ET}_{\mathrm{EC}}$ from eddy covariance at the TW during July 2013-December 2014 was 3.6 ( \pm 1.8$) \mathrm{mm}$; in summer the maximum daily $\mathrm{ET}_{\mathrm{EC}}$ had a peak of $9.3 \mathrm{~mm}$ and a mean daily value of $6.3 \mathrm{~mm}$ (Fig. 8).

$\mathrm{ET}_{\mathrm{EC}}$ variability was correlated with $\mathrm{ET}_{0}$ and leaf area index (LAI) variation. The total $\mathrm{ET}_{\mathrm{EC}}$ in late July 2013-December 2014, was of $1836.6 \mathrm{~mm}$. The mean ET herein obtained is very similar to the results of other related researches with similar TW plantations (Fermor et al., 2001, Zhou et al., 2009, Headley et al., 2012, Irmak et al., 2013).

The hourly mean sensible heat flux from surface renewal $\left(\mathrm{H}_{\mathrm{SR}}\right)$ was of $27.2( \pm 54.4) \mathrm{Wm}^{-2}$, with a summer mean value of $35( \pm 63)$ $\mathrm{Wm}^{-2}$. $\mathrm{ET}_{\mathrm{SR}}$, obtained as residual of Eq. (4), had a mean of $2.7( \pm 1.8)$ $\mathrm{mm} \mathrm{d}^{-1}$ (Fig. 8). The SR method was found reliable, easy to operate in the field and sustainable for long-term use over treatment wetland systems. The SR technique requires to be calibrated with EC system (Castellví et al., 2012). Fig. 8 shows the comparison between $\mathrm{ET}_{\mathrm{EC}}$ by eddy covariance system, $\mathrm{ET}_{\mathrm{SR}}$ estimated as the residual term of the energy balance equation when $\mathrm{H}$ is surface renewal-based and $\mathrm{ET}_{0}$ which was calculated with the FAO Penman-Monteith method. The values of $\mathrm{ET}_{\mathrm{SR}}$ and $\mathrm{ET}_{0}$ were on average about $89 \%$ of $\mathrm{ET}_{\mathrm{EC}}$.

The crop coefficient $\left(\mathrm{K}_{\mathrm{c}}\right)$, calculated as ratio of daily $\mathrm{ET}_{\mathrm{EC}}$ to $\mathrm{ET}_{0}$

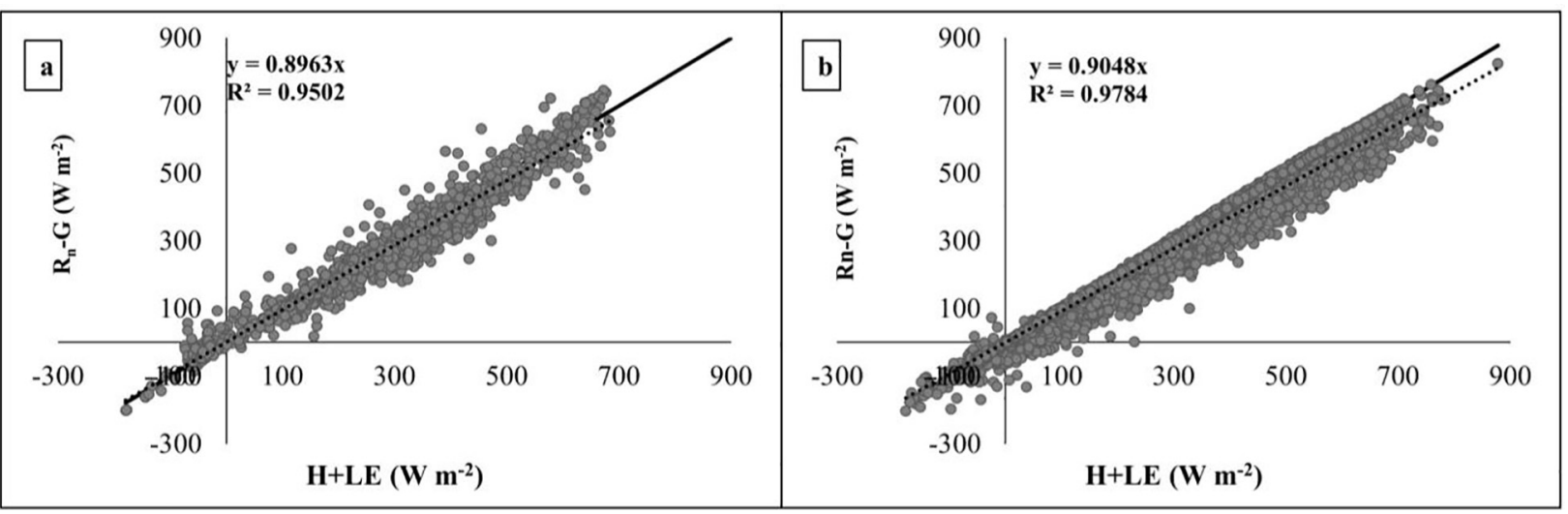

Fig. 6. Energy balance closure during 2013 (a) and 2014 (b) at the treatment wetland system. 


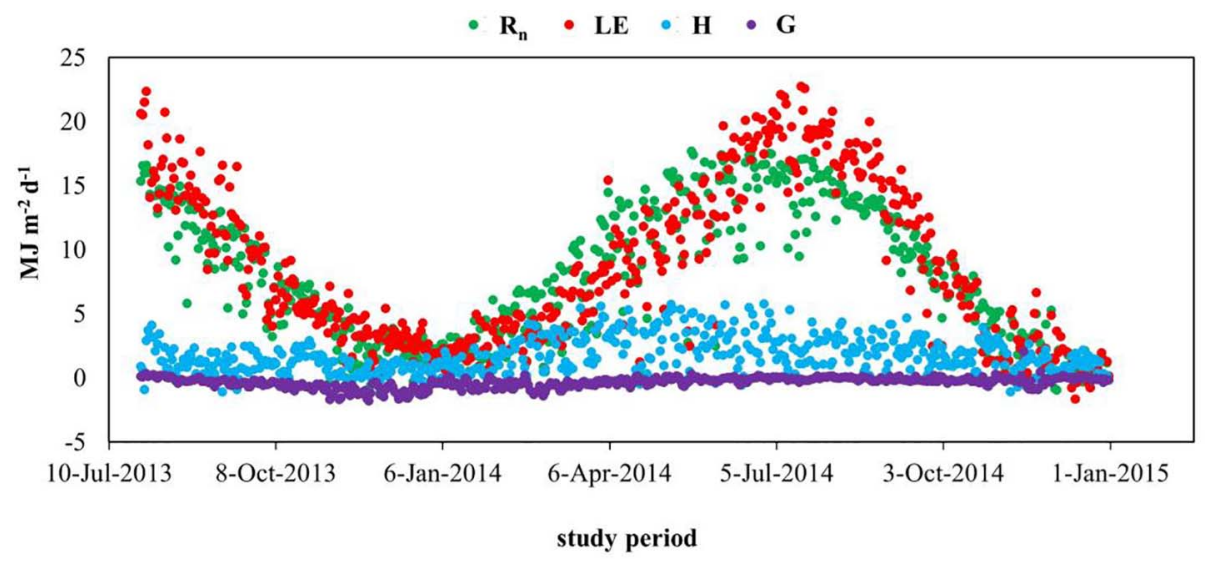

Fig. 7. Daily values of net radiation $\left(R_{n}\right)$, soil heat flux $(G)$, and eddy covariance sensible $(H)$ and latent heat (LE).

showed a daily variability (Fig. 9).

$\mathrm{K}_{\mathrm{c}}$ values exhibited a gradual increase from March onward, reached a peak in late July, and then went down again. The values of $\mathrm{K}_{\mathrm{c}}$ were within the range $0.1-2.9$, with a mean of $1.2( \pm 0.4)$. The value of $K_{c}$ for the Phragmites australis were within the range of crop coefficient values from other wetland studies (Drexler et al., 2008, Zhou et al., 2009).

\subsection{Results on water balance}

Decadal water balance for the TW system is presented in Fig. 10, with ET from Eq. (5), and the other variables directly measured.

The developing of the water balance was feasible and accurate in the period February-August 2014, but was problematic for some months of the hydrological year (data not showed) with negative values for the OUT term. The water budget indicated that, in the available period in 2014, ET had a mean of $6.6( \pm 2.5) \mathrm{mm}$, IN and OUT were in their average of $60.9( \pm 29.8) \mathrm{mm}$ and $56.3( \pm 28.9) \mathrm{mm}$, respectively. ET from water balance exceeded precipitation of about $80 \%$ and accounted for $3-25 \%$ of the IN received by the TW system (Fig. 11). Compared to ET coming from the water balance, the mean $\mathrm{ET}_{\mathrm{EC}}$ measured with the eddy covariance (EC) system was about 15\% lower $(5.6 \pm 2.4 \mathrm{~mm})$. During the monitored period, the wetland lost a total of $1379.4 \mathrm{~mm}$ of water through evapotranspiration. The total $\mathrm{ET}_{\mathrm{EC}}$ measured during the TW water balance period was of $1185.3 \mathrm{~mm}$.

The mean 10-days $\mathrm{K}_{\mathrm{c}}$ values relative to eddy covariance ET and water balance ET-based are reported in Fig. 12, with the 1:1 line.

$\mathrm{K}_{\mathrm{c}}$ values had a mean of $1.5( \pm 0.30)$ when ET was directly measured with EC, while the mean $\mathrm{K}_{\mathrm{c}}$ from water balance ET-based was $1.9( \pm 0.30$ ), with peaks around 5.0 during July 2014 (data not showed). The values of $\mathrm{K}_{\mathrm{c}}$ resulted from the two approaches were significantly correlated, thus suggesting the reliability of micrometeorological methods based on energy balance to estimate ET fluxes from TW systems.

\section{Discussion}

In this study the energy balance approach, based on the eddy covariance (EC), was adopted to determine ET fluxes in a TW used as tertiary wastewater treatment system for a small village in Easter Sicily, Italy. The surface renewal (SR) technique was also tested as alternative technique for estimating sensible heat fluxes $\left(\mathrm{H}_{\mathrm{SR}}\right)$. It only requires calibration using an EC sonic anemometer. But, the re-calibration is necessary if there are significant changes in the vegetation canopy (Paw et al., 2005). SR is a low cost system, which needs simple and basic maintenance operations.

The energy balance of the TW system revealed a dominance of LE, with $\mathrm{H}_{\mathrm{EC}}$ rarely exceeding.

Despite the footprint area of the EC tower was a complex surface, with areas of open water (i.e. storage reservoirs), soil and vegetation, the quite high energy balance closure has confirmed the good reliability of the technique to identify the energy partitions within the study system.

Results of ET energy balance were compared for a short period with ET values obtained from the resolution of the TW simplified water balance. The FAO-56 approach was applied for reference ET and $\mathrm{K}_{\mathrm{c}}$ determination. Total ET from EC in 2013-14 period of monitoring was about $1837 \mathrm{~mm}$ for the Phragmites australis. Data showed that daily ET varied in response to the LAI variation and, consequently, to the phenology of the species. ET fluxes increased rapidly once the leaves expanded and reached peak rates in July. ET at the TW system was generally higher than reference $\mathrm{ET}_{0}$ (total of about $1450 \mathrm{~mm}$ ). The

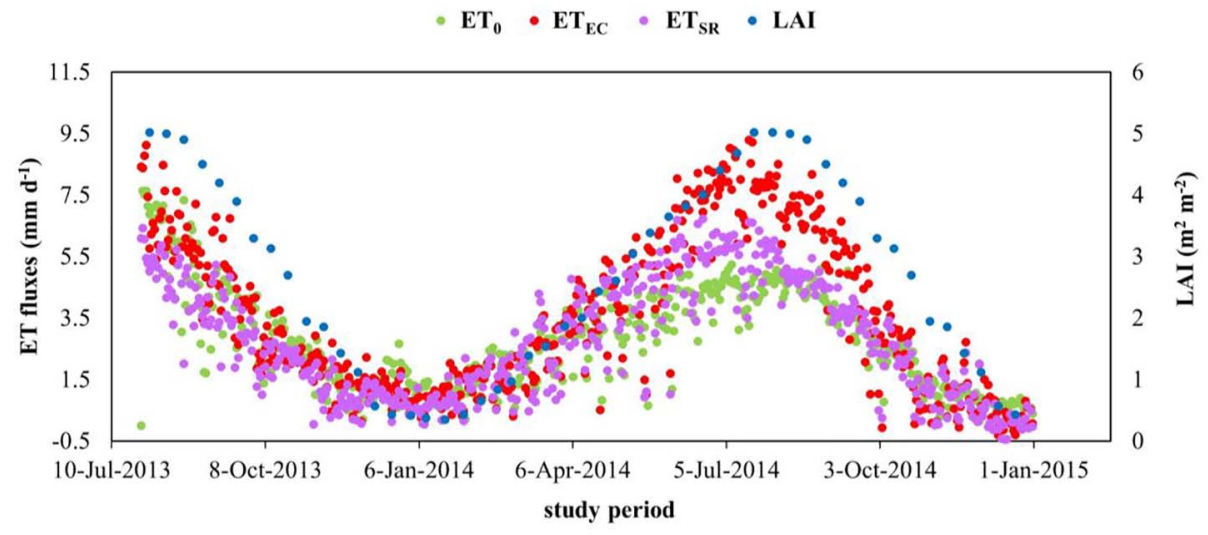

Fig. 8. Daily values $\mathrm{ET}_{\mathrm{EC}}(\mathrm{mm}), \mathrm{ET}_{\mathrm{SR}}(\mathrm{mm}), \mathrm{ET}_{0}(\mathrm{~mm})$ with $\mathrm{LAI}\left(\mathrm{m}^{2} \mathrm{~m}^{-2}\right)$ evolution during the study period. 


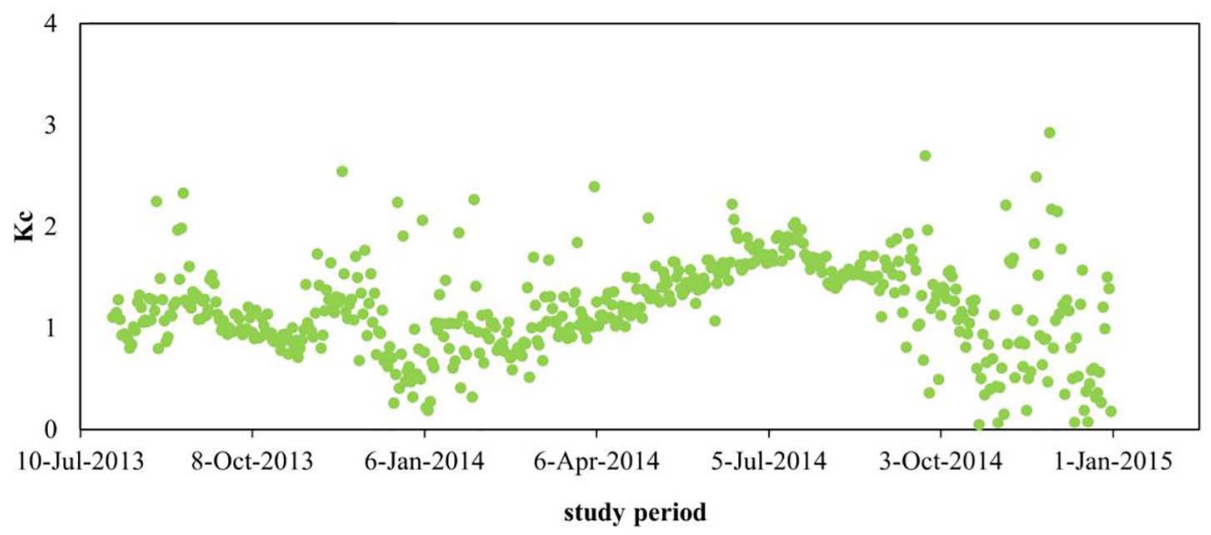

Fig. 9. Evolution of daily $\mathrm{K}_{\mathrm{c}}$ during the study period.

greatest difference between $\mathrm{ET}_{\mathrm{EC}}$ and $\mathrm{ET}_{0}$ occurred in the springsummer period of 2014, mainly as a result of the rapid vegetative growth of the species. On annual basis, $\mathrm{K}_{\mathrm{c}}$ obtained as ratio between $\mathrm{ET}_{\mathrm{EC}}$ and $\mathrm{ET}_{0}$-FAO56 based, was 1.24 at the study TW. On a daily scale, $\mathrm{K}_{\mathrm{c}}$ was highly variable, within a range consistent with outcomes of similar studies.

The results of this study are of a certain interest because, although improvements on measurements techniques, and the dominant role of ET in TW system, there are few studies in Italy with actual measurements of ET in treatment wetland systems. At the same experimental study site, TW ET has been estimated by Borin et al. (2011) (daily maximum of $37.8 \mathrm{~mm}$ for reed) and Milani and Toscano (2013) at pilot spatial scale using water balance and climatic methods $\left(\mathrm{K}_{\mathrm{c}}\right.$ up to 8.5 in August 2009).

In the particular case of the TW system of S. Michele di Ganzaria (Eastern Sicily), which is part of the municipal sewage treatment plant, the study of the ET fluxes is fundamental for the analysis of the system functioning and for understanding its role in the environmental control processes (e.g. water vapour, gases and energy exchanges).

Except for the pilot-scale applications, the results obtained in our study, by using both the water and energy budget approaches, are similar to those obtained at international level on comparable or wider scales of applications.

In particular, Zhou and Zhou (2009) adopted the eddy covariance technique to estimate the magnitude and the dynamics of ET (average of $1.9 \mathrm{~mm} \mathrm{~d}^{-1}$ during the growing season) over a reed marsh in Northeast China. Headley et al. (2012) adopted the water balance method for estimating ET in a pilot-scale treatment constructed wetlands in Australia (average ET $=7.0 \mathrm{~mm} \mathrm{~d}^{-1}$ ). Clulow et al. (2012) applied the micrometeorological SR method for estimating the ET fluxes (average of $3.2 \mathrm{~mm} \mathrm{~d}^{-1}$ in summer) from a costal wetland in South Africa. Irmak et al. (2013) applied a two-step approach based on the Bowen ration energy balance system to measure ET for a mixed wetland system in Nebraska-USA (average seasonal ET of $3.8 \mathrm{~mm} \mathrm{~d}^{-1}$ ). Anda et al. (2014) used a climatic approach to estimate ET (on annual scale average ET was between 2.1 and $7.7 \mathrm{~mm} \mathrm{~d}^{-1}$ ) of common reed in Hungary.

Our results are of interest also in relation to the limits of the application of the water balance technique for real-scale systems. In fact, developing a TW water balance using measured P, IN and OUT and estimated ET did not result accurate in the whole monitoring period, due to management problems of wastewater IN coming from the secondary conventional treatment plant (i.e. tricking filter) serving the area of study in Sicily.

Therefore, the energy balance monitoring approach can be considered as reliable and capable to reasonable well capture the mass and energy partitioning within the heterogeneous TW system.

\section{Conclusions}

The main result coming from this research is the feasibility of the micrometeorological methods (based on EC or alternatively on SR for sensible heat fluxes) to be applied in such heterogeneous soil-plant-atmosphere environment.

The following main outcomes can be summarized:

- evapotranspiration in the TW system is highly correlated with vegetation growth;

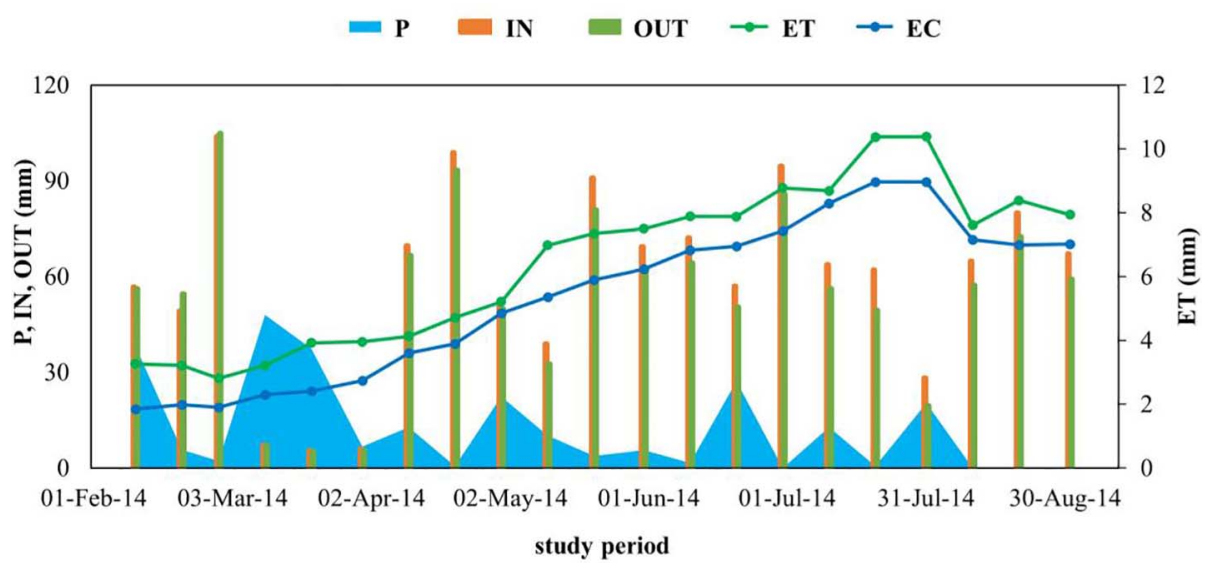

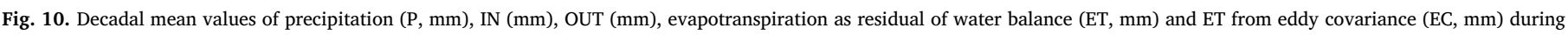
February-August 2014. 


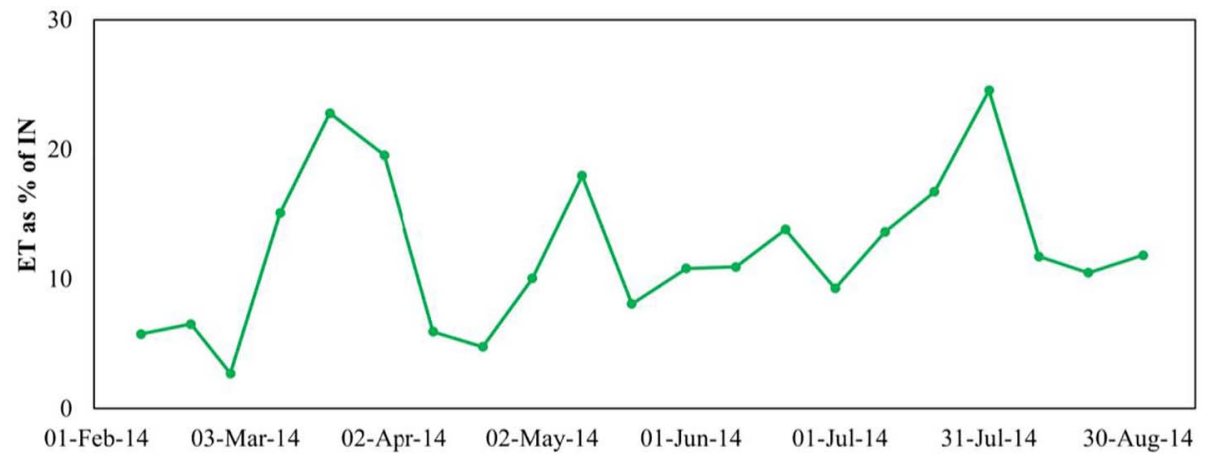

study period

Fig. 11. Mean 10-days mean percentage of influent wastewater IN (mm) that was lost via ET from the TW system.

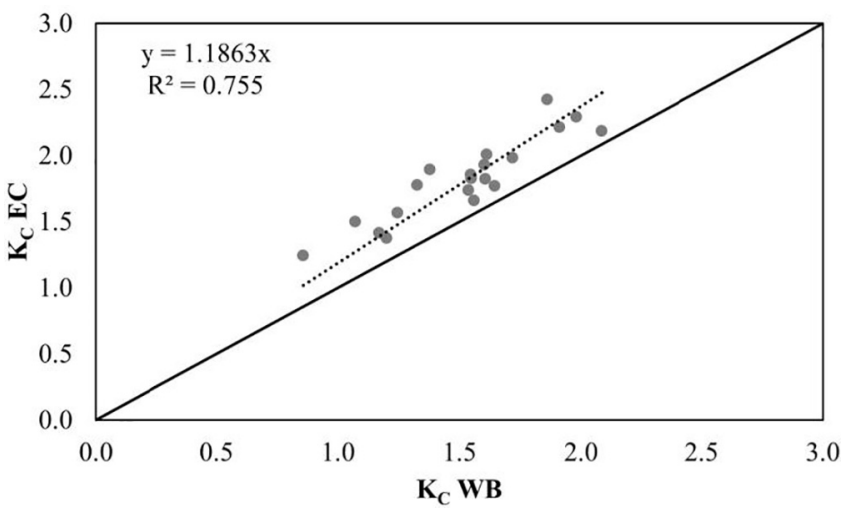

Fig. 12. 10-day average $K_{c}$ from water balance (WB) and eddy covariance (EC) approaches.

- average loss of available energy for ET is of about $65 \%$ during the study periods;

- surface renewal is a valid alternative to EC for estimating sensible heat fluxes;

- evapotranspiration from TW water balance is overestimated by about $15 \%$ compared to EC.

Finally, further studies will imply the analysis of the most suitable aquatic vegetation that would minimize ET losses from TW systems used for agricultural reuse purposes.

\section{Acknowledgements}

This research activity was carried within the WATER4CROPS EU FP7 Project - Integrating biotreated wastewater reuse and valorization with enhanced water use efficiency to support the Green Economy in EU and India, financed by EU (FP7 grant No. 311933).

\section{References}

Abtew, W., Melesse, A., 2013. Wetland evapotranspiration. In: Evaporation and Evapotranspiration. Springer, Netherland, pp. 93-108.

Abtew, W., Obeysekera, J., 1995. Lysimeter study of evapotranspiration of cattails and comparison of three estimation methods. Trans. ASAE 38 (1), 121-129.

Acreman, M.C., Harding, R.J., Lloyd, C.R., McNeil, D.D., 2003. Evaporation characteristics of wetlands: experience from a wetgrassland and a reedbed using eddy correlation measurements. Hydrol. Earth Syst. Sci. Discuss. 7 (1), 11-21.

Allen, R.G., Pereira, L.S., Raes, D., Smith, M., 1998. Crop evapotranspiration-Guidelines for computing crop water requirements-FAO Irrigation and drainage paper 56. FAO, Rome 300 (9), D05109.

Anda, A., da Silva, J.A.T., Soos, G., 2014. Evapotranspiration and crop coefficient of common reed at the surroundings of Lake Balaton, Hungary. Aquatic Botany 116, 53-59.

Annandale, J.G., Jovanovic, N.Z., Campbell, G.S., Du Sautoy, N., Benade, N., 2003. A two- dimensional water balance model for micro-irrigated hedgerow tree crops. Irrigation Sci. 22 (3-4), 157-170.

Aubinet, M., Grelle, A., Ibrom, A., Rannik, U., Moncrieff, J., Foken, T., Kowalski, P., Martin, P., Berbigier, P., Bernhofer, C., Clement, R., Elbers, J., Granier, A., Grunwald, T., Morgenster, K., Pilegaard, K., Rebmann, C., Snijders, W., Valentini, R., Vesala, T., 2000. Estimates of the annual net carbon and water exchange of Europeran forests: the EUROFLUX methodology. Adv. Ecological Res. 30, 113-175.

Barbagallo, S., Cirelli, G., Consoli, S., Somma, F., 2003. Wastewater quality improvement through storage: A case study in Sicily. Water Sci. Technol. 64 (5), 1032-1039.

Barbagallo, S., Cirelli, G.L., Marzo, A., Milani, M., Toscano, A., 2011. Hydraulic behavior and removal efficiencies of two H-SSF constructed wetlands for wastewater reuse with different operational life. Water Sci. Technol. 47 (7-8), 169-176.

Barbagallo, S., Cirelli, G.L., Consoli, S., Licciardello, F., Marzo, A., Toscano, A., 2012. Analysis of treated wastewater reuse potential for irrigation in Sicily. Water Sci. Technol. 65 (11), 2024-2033.

Borin, M., Milani, M., Salvato, M., Toscano, A., 2011. Evaluation of Phragmites australis (Cav.) Trin. evapotranspiration in northern and southern Italy. Ecological Eng. 37 (5), 721-728.

Burba, G.G., Verma, S.B., Kim, J., 1999. Surface energy fluxes of Phragmites australis in a prairie wetland. Agric. Forest Meteorol. 94 (1), 31-51.

Castellví, F., Consoli, S., Papa, R., 2012. Sensible heat flux estimates using two different methods based on surface renewal analysis. A study case over an orange orchard in Sicily. Agric. Forest Meteorol. 152, 58-64.

Castorina, A., Consoli, S., Barbagallo, S., Branca, F., Farag, A., Licciardello, F., Cirelli, G.L., 2016. Assessing environmental impacts of constructed wetland effluents for vegetable crop irrigation. Int. J. Phytoremediation 18 (6), 626-633.

Cirelli, G.L., Consoli, S., Di Grande, V., Milani, M., Toscano, A., 2007. Subsurface constructed wetlands for wastewater treatment and reuse in agriculture: five years of experiences in Sicily, Italy. Water Sci. Technol. 56 (3), 183-191.

Consoli, S., Papa, R., 2013. Corrected surface energy balance to measure and model the evapotranspiration of irrigated orange orchards in semi-arid Mediterranean conditions. Irrigation Sci. 31 (5), 1159-1171.

Clulow, A.D., Everson, C.S., Mengistu, M.G., Jarmain, C., Jewitt, G.P.W., Price, J.S., Grundling, P.L., 2012. Measurement and modelling of evaporation from a coastal wetland in Maputaland, South Africa. Hydrol. Earth Syst. Sci. 16 (9), 3233-3247.

Drexler, J.Z., Snyder, R.L., Spano, D., Paw, U., Tha, K., 2004. A review of models and micrometeorological methods used to estimate wetland evapotranspiration. Hydrol. Process. 18 (11), 2071-2101.

Drexler, J.Z., Anderson, F.E., Snyder, R.L., 2008. Evapotranspiration rates and crop coefficients for a restored marsh in the Sacramento-San Joaquin Delta, California, USA. Hydrological Process. 22 (6), 725-735.

Fermor, P.M., Hedges, P.D., Gilbert, J.C., Gowing, D.J.G., 2001. Reedbed evapotranspiration rates in England. Hydrological Processes 15 (4), 621-631.

Foken, T., 2008. Micrometeorology. Springer, pp. 328.

Goulden, M.L., Litvak, M., Miller, S.D., 2007. Factors that control Typha marsh evapotranspiration. Aquatic Botany 86 (2), 97-106.

Headley, T.R., Davison, L., Huett, D.O., Müller, R., 2012. Evapotranspiration from subsurface horizontal flow wetlands planted with Phragmites australis in sub-tropical Australia. Water Res. 46 (2), 345-354.

Kadlec, R.H., Wallace, S., 2008. Treatment wetlands. CRC Press.

Kaimal, J.C., Finnigan, J.J., 1994a. Atmospheric boundary layer flows: their structure and measurement. Oxford University Press.

Idso, S.B., 1981. Relative rates of evaporative water losses from open and vegetation convered water bodies. Water Resourc. Bullet. 17, 46-48.

Idso, S.B., Anderson, M.G., 1988. A comparison of two recent studies of transpirational water loss from emergent aquatic macrophytes. Aquatic Botany 31, 191-195.

Irmak, S., Kabenge, I., Rudnick, D., Knezevic, S., Woodward, D., Moravek, M., 2013. Evapotranspiration crop coefficients for mixed riparian plant community and transpiration crop coefficients for Common reed, Cottonwood and Peach-leaf willow in the Platte River Basin, Nebraska-USA. J. Hydrol. 481, 177-190.

Kaimal, J.C., Finnigan, J., 1994b. Atmospheric Boundary Layer Flows: Their Structure and Measurement. Oxford University Press, New York, pp. 255-261.

Mao, L.M., Bergman, M.J., Tai, C.C., 2002. Evapotranspiration measurement and 
estimation of three wetland environments in the upper St. Johns River Basin, Florida. J. Am. Water Resour. As 38, 1271-1285.

Mauder, M. \& Foken, T., 2004. Documentation and instruction manual of the eddy covariance software package TK2. Universität Bayreuth, Abt. Mikrometeorologie, Arbeitsergebnisse, http://www.geo.unibayreuth.de/mikrometeorologie/ARBERG, pp. 26-44.

Mauder, M., Oncley, S.P., Vogt, R., Weidinger, T., Ribeiro, L., Bernhofer, C., Foken, T., Kosiek, W., De Bruin, H.A.R., Liu, H., 2007. The energy balance experiment EBEX2000. Part II. Intercomparison of eddy-covariance sensors and post-field data processing methods. Boundary-Layer Meteorol. 123 (1), 29-54.

Milani, M., Toscano, A., 2013. Evapotranspiration from pilot-scale constructed wetlands planted with Phragmites australis in a Mediterranean environment. J. Environ. Sci. Health, Part A 48 (5), 568-580.

Moro, M.J., Domingo, F., López, G., 2004. Seasonal transpiration pattern of Phragmites australis in a wetland of semi-arid Spain. Hydrological Process. 18 (2), 213-227.

Noormets, A., Ewers, B., Sun, G., Mackay, S., Zheng, D., McNulty, S.G., Chen, J., 2006 Water and carbon cycles in heterogeneous landscapes: an ecosystem perspective. From Theory to Application, Ecology of Hierarchical Landscapes, pp. 89-123.

Paw U K. T., Brunet Y., 1991. A surface renewal measure of sensible heat flux density. Proc. of the 20th Conference on Agriculture and Forest Meteorology, Salt Lake City, 52-53.

Paw, U.K.T., Qiu, J., Su, H.-B., Watanabe, T., Brunet, Y., 1995. Surface renewal analysis: a new method to obtain scalar fluxes. Agric. Forest Meteorol. 74, 119-137.

Paw, U.K.T., Snyder, R.L., Spano, D., Su, H., 2005. Surface renewal estimates of scalar exchange. Agronomy 47, 455.

Peacock, C.E., Hess, T.M., 2004. Estimating evapotranspiration from a reed bed using the Bowen ratio energy balance method. Hydrological Process. 18 (2), 247-260.

Price, J.S., 1994. Evapotranspiration from a lakeshore Typha marsh on Lake Ontario. Aquatic Botany 48 (3-4), 261-272.

Rejšková, A., Čížková, H., Brom, J., Pokorný, J., 2012. Transpiration, evapotranspiration and energy fluxes in a temperate wetland dominated by Phalaris arundinacea under hot summer conditions. Ecohydrology 5 (1), 19-27.

Siedlecki, M., Pawlak, W., Fortuniak, K., Zieliński, M., 2016. Wetland evapotranspiration: eddy covariance measurement in the biebrza Valley, Poland. Wetlands 36 (6), 1055-1067.

Snyder, R.L., Spano, D., Paw, U.K.T., 1996. Surface renewal analysis for sensible and latent heat flux density. Boundary-Layer Meteorol. 77 (3-4), 249-266.

Spano, D., Duce, P., Snyder, R. L., Paw, U K. T., 1997. Surface renewal estimates of evapotranspiration. Tall canopies. In II International Symposium on Irrigation of Horticultural Crops 449 (pp. 63-68)

Soucha, C., Wolfe, C.P., Grimmtind, C.S.B., 1996. Wetland evaporation and energy partitioning: Indiana dunes national lakeshore. J. Hydrol. 184 (3), 189-208.

South, C., Susan, C., Grimmond, B., Wolfe, C.P., 1998. Evapotranspiration rates from wetlands with different disturbance histories: Indiana Dunes National Lakeshore. Wetlands 18 (2), 216-229.

Toscano, A., Hellio, C., Marzo, A., Milani, M., Lebret, K., Cirelli, G.L., Langergraber, G., 2013. Removal efficiency of a constructed wetland combined with ultrasound and UV devices for wastewater reuse in agriculture. Environ. Technol. 34 (15), 2327-2336.

Toscano, A., Marzo, A., Milani, M., Cirelli, G.L., Barbagallo, S., 2015. Comparison of removal efficiencies in Mediterranean pilot constructed wetlands vegetated with different plant species. Ecological Eng. 75, 155-160.

Van Atta, C.W., 1977. Effect of coherent structures on structure functions of temperature in the atmospheric boundary layer. Archiwum Mechaniki Stosowanej 29 (1), 161-171.

Van Heerden, P. S., Crosby, C. T., Grové, B., Benadé, N., Theron, E., Schulze, R. E., Tewolde, M. H., 2009. Integrating and updating of SAPWAT and PLANWAT to create a powerful and userfriendly irrigation planning tool. Water Research Commission Report No. TT, 391(08).

Wilson, K.B., Baldocchi, D.D., 2000. Esimating annual net ecosystem exchange of carbon over five years at a deciduous forest in the southern United States. Agric. Forest Meteorol. 100 (8).

Zhou, L., Zhou, G., 2009. Measurement and modelling of evapotranspiration over a reed (Phragmites australis) marsh in Northeast China. J. Hydrol. 372 (1), 41-47.

Zhou, L., Zhou, G., Jia, Q., 2009. Annual cycle of CO 2 exchange over a reed (Phragmites australis) wetland in Northeast China. Aquatic Botany 91 (2), 91-98. 